\title{
Characterization of esterase activity in the Bianchetta trevigiana grape variety under reducing conditions
}

This article was published in the following Dove Press journal:

International Journal of Wine Research

II October 2012

Number of times this article has been viewed

\author{
Giovanna Lomolino \\ Anna Lante \\ Department of Agronomy Food \\ Natural Resources Animals and \\ Environment, Agripolis, Università \\ di Padova Viale dell'Università, \\ Padova, Italy
}

Background and methods: While extensive research has been carried out on the enzymes responsible for ester synthesis and hydrolysis by wine strains of Saccharomyces cerevisiae, grape esterase activity is limited. In this study, the autochthonous grape variety, Bianchetta trevigiana, widespread in the Prosecco wine production area of Treviso, Conegliano, and Asolo, Italy, was characterized according to its esterase activity. Because grape skin is very rich in compounds which impart qualitative characteristics to wine, the study of esterase was carried out on this part of the fruit.

Results: During enzyme extraction from grape skin, the presence of the reducing agent, $\beta$-mercaptoethanol, allowed a better protein yield but reduced esterase activity. Further addition of increasing doses of reducing agents to grape skin protein extract, such as of $\mathrm{K}_{2} \mathrm{~S}_{2} \mathrm{O}_{5}$ (used in winemaking) and DTT, reduced or inhibited esterase activity. Even though the zymographic profiles of the extracts obtained with and without $\beta$-mercaptoethanol were qualitatively equal, the intensity of enzymatic bands, measured by densitometry, was different.

Conclusion: The presence of reducing agents affected the activity of grape skin esterase, and given that this enzyme is involved in the hydrolysis and synthesis of esters, which are important compounds responsible for the flavor of wine, addition of reducing agents could affect the aromatic profile of wine.

Keywords: esterase, grape, reducing agent, wine

\section{Introduction}

Because wine is often considered an expression of a territory, autochthonous grape varieties contribute a unique and original element to the distinctive character and identity of local culture. Many grape varieties, considered a resource in viticulture and a renewed opportunity for Italian winemaking, have been recovered. Bianchetta trevigiana, a grape variety known since the sixteenth century, is widespread in wine production in the area of Prosecco (Treviso, Conegliano, and Asolo, Italy). ${ }^{1}$ It is an ancient white variety that was traditionally used for wine made by both grape skin maceration and fermenting without the presence of grape skin. Winemaking practices affect the characteristics of the final product by transforming, improving, or inhibiting the expression of the varietal characteristics of the grape.

In general, wine is a complex mixture of hundreds of compounds, many of which contribute to the colour, mouthfeel, and aromatic properties of this beverage. The distinctive flavor and aroma of wine is determined by many variables, including grape variety, viticulture and winemaking practices, and wine maturation and storage conditions. The aroma of wine has received much research attention over recent 
decades, with numerous components being identified as playing a role in specific tasting notes. ${ }^{2}$ Among them, esters are the largest group of the hundreds of aroma compounds formed during alcoholic fermentation. ${ }^{3}$ Their sensory threshold is very low, and thus they have a strong influence on the aroma of alcoholic beverages, giving characteristic flavors not only to wine ${ }^{4}$ but also, for example, to beer ${ }^{5}$ and sake. ${ }^{6}$ Therefore, the study of enzymatic activity which affects the ester content and spectrum is of primary importance in elucidating the mechanisms leading to formation of the aroma profile of a fermented beverage such as wine. The enzymatic accumulation of esters in wine during fermentation is known to be the result of the balance of enzymatic synthesis and hydrolysis reactions, involving esterases (EC 3.1.1.1). ${ }^{7,8}$ Esterolytic activity during wine production has the potential to increase or decrease the amount of esters present in wine and therefore its perceived quality.

Esterases are expressed in yeast strains used for alcoholic beverage production, and their involvement in affecting the aroma of such beverages has been the subject of several studies. By regulating the equilibrium between esters and free acids, esterases are likely have some role in the synthesis of esters, but seem to be primarily involved in their breakdown. ${ }^{4,5,9,10}$ The source of esterase activity in wine is primarily microorganisms, but esterase activity also comes from the addition of pectolytic enzymes with residual activity such as $\beta$-glucosidase and esterase, as well as the grape itself. ${ }^{3,8}$ A range of microorganisms come into contact with wine during its production, and thus their metabolic activities and synthetic and degradative enzymes may influence the aroma of wine. A large amount of esters are formed during primary fermentation by yeast and in particular by Saccharomyces cerevisiae; after this, lactic acid bacteria, which exhibit substantial ester synthesis and hydrolysis activity, can contribute by increasing or decreasing ester concentrations. $^{11-14}$

Although extensive research has been carried out on the enzymes responsible for ester synthesis and hydrolysis by wine strains of $S$. cerevisiae,${ }^{15-17}$ the esterase activity of the grape itself is limited. ${ }^{18}$ Even though in many cases their physiological role is unknown, esterases (EC 3.1.1.1), which are ubiquitous enzymes in living eukaryotic cells, are often used to characterize organisms by their isoenzymatic profile. Esterases have been studied in several fermentative processes and in food technology. To expand our knowledge about the esterase activity of grape skin from the autochthonous variety B. trevigiana, we quantified and visualized its esterase activity using electrophoretic techniques. Moreover, we studied the enzyme under reducing conditions, which are very common in winemaking practices.

\section{Materials and methods}

Samples of the white grape, B. trevigiana, were obtained at commercial maturity from a local winery. Grapes were mold-free and washed several times before storage at $-80^{\circ} \mathrm{C}$. Extraction of enzymes from the grape skin was carried out using the method reported by Zocca et $\mathrm{al}^{19}$ and Barnavon et al, ${ }^{20}$ with some modifications. Grape skins (40 g) were frozen with liquid nitrogen in a mortar and crushed. Next, $50 \mathrm{~g}$ of grape skin powder was resuspended in $100 \mathrm{~mL}$ of $0.5 \mathrm{M}$ Tris- $\mathrm{HCl} \mathrm{pH} 8.5$ buffer with $1 \%(\mathrm{w} / \mathrm{v})$ Triton X-100 (BDH Chemicals, Kingston upon Hull, UK), $20 \%(\mathrm{w} / \mathrm{v})$ glycerol (v/v), 5\% polyvinyl polypyrrolidone (Sigma-Aldrich, St Louis, MO), and $2 \mathrm{M} \mathrm{NaCl}$. A second sample of $50 \mathrm{~g}$ of grape skin was treated in the same manner but with the addition of $14 \mu \mathrm{L}$ of $\beta$-mercaptoethanol. The two samples were called no B and B, respectively. Both samples were shaken for 6 hours in an ice bath.

The homogenate was centrifuged for 30 minutes at $4^{\circ} \mathrm{C}$ and 10,000 rpm, and the supernatant was retained. After filtration (Whatman Number 1, Maidstone, UK and Millipore $0.22 \mu \mathrm{m}$, Milford, MA), the solution was dialyzed in distilled water overnight at $4^{\circ} \mathrm{C}$ (Spectrum membrane, $8 \mathrm{kDa}$, Rancho Dominguez, CA). The dialyzed samples were freeze-dried at $-40^{\circ} \mathrm{C}$ (Edwards Mini Fast 1700 (Edwards Alto Vuoto, Milan, Italy)) and stored at $-20^{\circ} \mathrm{C}$. Protein quantification for the B and no B samples was carried out according to the Bradford ${ }^{21}$ method (Pierce, Rockford, IL), with bovine serum albumin (Bio-Rad Laboratories, Milan, Italy) as a standard.

\section{Esterase activity}

Esterase activity was determined using the method described by Bardi et $\mathrm{al}^{22}$ as modified by Lomolino et al. ${ }^{23}$ Lyophilized skin grape extract (10 mg each of B and no B) was dissolved in $100 \mu \mathrm{L}$ of Tris-buffered saline ( $\mathrm{pH} 7.2)$ and centrifuged at $2000 \times \mathrm{g}$ for 5 minutes. Substrates $[20 \mathrm{mg}$ each of p-nitrophenyl acetate (PNPA), 2-naphthyl acetate (2NA), 2-naphthyl butyrate (2NB), and fluorescein diacetate (FDA) obtained from Sigma] were dissolved in $1 \mathrm{~mL}$ of $10 \%$ Triton $\mathrm{X}-100(\mathrm{v} / \mathrm{v})$. The enzymatic test was carried out as follows: $100 \mu \mathrm{L}$ of substrate, $10 \mu \mathrm{L}$ of the no B sample or $8 \mu \mathrm{L}$ of the B sample and Tris-buffered saline $\mathrm{pH} 7.2$ to a final volume of $1.5 \mathrm{~mL}$. A blank was made as above with samples omitted.

Esterase activity was also studied in the presence of reducing agents such as $\mathrm{K}_{2} \mathrm{~S}_{2} \mathrm{O}_{5}$ and threo-1,4-dimercapto2,3-butanediol (DTT). Increasing quantities of $\mathrm{K}_{2} \mathrm{~S}_{2} \mathrm{O}_{5}$ and 
DTT from a solution of $0.1 \mathrm{M}$ were added $(0-300 \mathrm{mg} / \mathrm{L}$ and $0-210 \mathrm{mg} / \mathrm{L}$, respectively) to the test tubes prepared as described above. In this case, esterase activity was studied in presence of $2 \mathrm{NA}$.

Enzyme activity was determined after keeping the test tubes in a water bath at $37^{\circ} \mathrm{C}$ for 30 minutes; when esterase activity was tested in the presence of $2 \mathrm{NA}$, the reaction was stopped by adding $200 \mu \mathrm{L}$ of Fast Blue BB salt $1 \mathrm{mg} / \mathrm{mL}$ (Sigma-Aldrich, St Louis, MO) in water. After 10 minutes, the samples were read at $500 \mathrm{~nm}$. For esterase activity studied with PNPA, quantification was done at $400 \mathrm{~nm}$. In the presence of FDA, esterase activity was measured with a FP-920 spectrofluorometer [Jasco Inc, Easton, MD] with excitation at $490 \mathrm{~nm}$ and emission at $514 \mathrm{~nm}$. One unit of esterase activity was defined as the release of $1 \mu \mathrm{g}$ of p-nitrophenol, 2-naphthol, and fluorescein by $1 \mu \mathrm{g}$ of esterasecontaining protein extract at $37^{\circ} \mathrm{C}$ under assay conditions. The results are always the mean of six replications.

\section{Electrophoresis}

All electrophoretic procedures were carried out at room temperature in a Mini-Protean 2 apparatus (Bio-Rad Laboratories). Sodium dodecyl sulfate polyacrylamide gel electrophoresis (SDS-PAGE) was performed according to Laemmli, ${ }^{24}$ with a total polyacrylamide concentration of $12 \%(\mathrm{w} / \mathrm{v})$. Ten milligrams of freeze-dried powder were solubilized with $700 \mu \mathrm{L}$ of Milli-Q (Millipore, Bedford, MA) $\mathrm{H}_{2} \mathrm{O}$ and $300 \mu \mathrm{L}$ of $1.33 \mathrm{M}$ Tris ( $\mathrm{pH} 7.4$ ), glycerol $40 \%$ $\mathrm{v} / \mathrm{v}, 8 \% \mathrm{SDS} \mathrm{w} / \mathrm{v}$ buffer, and 1\% (w/v) 2-mercaptoethanol. SDS-PAGE was carried out at $80 \mathrm{~V}$ until the tracking dye, bromophenol blue, ran off the gel. Gels were stained with Coomassie Brilliant Blue R-25013 to visualize total proteins. When enzymatic activity was visualized, ${ }^{25} 20 \mathrm{mg}$ of FDA or $2 \mathrm{NA}$ and Fast Blue BB was added, and the gel was incubated at $37^{\circ} \mathrm{C}$ for 45 minutes in $100 \mathrm{~mL}$ Tris-buffered saline $\mathrm{pH} 7.2$.

Deriphat-PAGE (D-PAGE) in $8.5 \%(\mathrm{w} / \mathrm{v})$ total polyacrylamide gels was performed in the presence of $0.1 \%$ $(\mathrm{w} / \mathrm{v})$ disodium-n-lauryl- $\beta$-iminodipropionate (Deriphat) in the cathodic buffer (12.5 mM Tris, $96 \mathrm{mM}$ glycine $).^{25}$ Ten milligrams of freeze-dried powder was solubilized with the cathodic buffer to which was added $10 \% \mathrm{w} / \mathrm{v}$ glycerol, and D-PAGE was carried out at $80 \mathrm{~V}$ until the tracking dye, bromophenol blue, ran off the gel. Esterase activity was detected by incubating the gel in $100 \mathrm{~mL}$ of Tris-buffered saline containing $20 \mathrm{mM} 2 \mathrm{NA}$ and $2 \mathrm{NB}$ at $37^{\circ} \mathrm{C}$ for 45 minutes and $20 \mathrm{mg}$ of Fast Blue BB was added. To obtain the fluorescent zymogram, $20 \mathrm{mg}$ of FDA was dissolved in
$2 \mathrm{~mL}$ of acetone and added to $100 \mathrm{~mL}$ of Tris-buffered saline. After 10 minutes of incubation at $37^{\circ} \mathrm{C}$, the zymogram was visualized under ultraviolet light. The negative control was an electrophoresis gel treated as above and heated at $100^{\circ} \mathrm{C}$ for 5 minutes in Tris-buffered saline containing $50 \%(\mathrm{v} / \mathrm{v})$.

Gel images were acquired with a digital camera, analyzed with the Gel Doc 1000 system (Bio-Rad Laboratories) and studied densitometrically using Molecular Analyst software (Bio-Rad Laboratories). All data are reported as the mean \pm standard deviation of three replicates.

\section{Statistical analysis}

The mean, standard deviation, and the coefficient of variation were calculated. Furthermore, the data were analyzed by Excel and CoStat (version 6.312, CoHort Software, Berkeley, CA). The analysis was performed using an independent samples $t$-test and Tukey test procedure. $P$ values $<0.05$ were regarded as statistically significant.

\section{Results and discussion}

Esterase activity is very important in enology because it is involved in the synthesis and hydrolysis of esters, which play an important role in defining the organoleptic properties of wine. ${ }^{27}$ Additionally, esterase releases grape skin phenols, such as gallic acid, which are initially present in the gallate flavonoid form and are then hydrolyzed by the enzyme and released into the wine in high quantities, especially when the wine is obtained by grape skin maceration. ${ }^{28}$ Taking into account the technological importance of esterase, this activity was studied in the $B$. trevigiana extract obtained in both reducing $(\mathrm{B})$ and non-reducing (no B) conditions. In this way, it was possible to compare the enzyme behavior in both situations.

To extract and purify partially a protein sample from grape skin for electrophoretic analysis, it was necessary to overcome some challenges due to the complex composition of the plant matrix, the high content of polyphenols, and the low concentration of proteins. Samples were extracted with and without $\beta$-mercaptoethanol (B and no B, respectively). The presence of the reducing agent was necessary to obtain a higher yield from the protein extraction and to determine if it could affect the esterase activity of grape skin. The results show that it is possible to maintain the enzyme activity and to have a good protein extraction yield (29.5 $\mu \mathrm{g} / \mathrm{mg}$ and $18.7 \mu \mathrm{g} / \mathrm{mg}$ lyophilized powder for B and no B samples, respectively). Lyophilization allowed storage of samples for a long period of time with retention of catalytic activity. Water molecules sometimes constitute 
part of the catalytic sites of enzymes, and their elimination with lyophilization can inactivate the enzymes, but this did not prove to be the case for these enzymes. $\mathrm{NaCl}$, glycerol, Triton, and Tris- $\mathrm{HCl}$ can all act to protect and stabilize catalytic sites. ${ }^{29}$

Esterase activities of the two samples were tested in the presence of four substrates, ie, 2NA, 2NB, FDA, and PNPA. Table 1 shows that the enzyme is present in the two extract preparations of $B$. trevigiana grape skin, in agreement with previous results. ${ }^{19,30}$ These authors also confirm the localization of esterases to the grape skin and demonstrate that these esterases have a higher affinity for synthetic esters of acetic acid than the butyric one. As shown in Table 1, the highest activity is present in the no $\mathrm{B}$ sample. The ratio between the activity of the no B sample and the B sample for all four tested esters is, on average, 2.04, with a coefficient of variation of $6 \%$. The low esterase activity of the B sample could be due to the presence of the reducing agent during extraction that partially inhibits the enzyme. The reducing agent, $\beta$-mercaptoethanol, should be completely kept away during the dialysis and freeze-drying of the sample. It is possible that the elimination of $\beta$-mercaptoethanol might result in the re-establishment of the native form of the enzyme; however, our results seem to demonstrate that reducing conditions result in an irreversible change that lowers the esterase activity.

In order to study the effect of reducing agents on esterase activity, increasing doses of $\mathrm{K}_{2} \mathrm{~S}_{2} \mathrm{O}_{5}$ and DTT (used in enology and in laboratory tests, respectively), were added to the two samples. We considered the possibility that addition of reducing agents could alter the analytical conditions used for the enzymatic assay with each of the four substrates. Other authors ${ }^{31}$ have demonstrated that addition of either DTT or $\beta$-mercaptoethanol to the reaction mixture causes

Table I Esterase activity of grape skin of Bianchetta trevigiana extracted with (B) and without $\beta$-mercaptoethanol (no B), and quantified in the presence of $2 \mathrm{NA}, 2 \mathrm{NB}, \mathrm{FDA}$, and PNPA

\begin{tabular}{lrc}
\hline & B & no B \\
\hline 2NA & $0.08770 \pm 0.003 \mathrm{I}^{\mathrm{b}}$ & $0.169 \pm 0.052^{\mathrm{a}}$ \\
2NB & $0.0242 \pm 0.0022^{\mathrm{b}}$ & $0.055 \mathrm{I} \pm 0.0022^{\mathrm{a}}$ \\
FDA & $0.0409 \pm 0.0068^{\mathrm{b}}$ & $0.0807 \pm 0.0028^{\mathrm{a}}$ \\
PNPA & $0.032 \pm 0.0029^{\mathrm{b}}$ & $0.0675 \pm 0.0028^{\mathrm{a}}$ \\
\hline
\end{tabular}

Notes: One unit of esterase activity is defined as $\mu \mathrm{g}$ of p-nitrophenol, 2-naphthol, and fluorescein released by the hydrolysis of esters by I $\mu \mathrm{g}$ of protein extract containing esterase, at $37^{\circ} \mathrm{C}$, under assay conditions; a All values were based on six different samples; All assays were done in triplicate, and data is presented as mean \pm standard deviation. In each sample's line, values followed by the same letter are not significantly different $(P<0.05)$, as measured by the Tukey's multiple range test.

Abbreviations: 2NA, 2-naphthyl acetate; 2NB, 2-naphthyl butyrate PNPA, $\mathrm{p}$-nitrophenyl acetate; FDA, fluorescein diacetate. decomposition of the chromogenic p-nitrophenyl ester, leading to nonspecific color formation. In this research, with increasing doses of reducing agents, PNPA and FDA became increasingly yellow and fluorescent, respectively (data not shown). On the contrary, the naphthyl esters, $2 \mathrm{NA}$ and $2 \mathrm{NB}$, were stable. For this reason, the esterase activity of the two extracts was studied using $2 \mathrm{NA}$ in the presence of the two reducing agents. Increasing doses of $\mathrm{K}_{2} \mathrm{~S}_{2} \mathrm{O}_{5}(0-300 \mathrm{mg} / \mathrm{L})$ and DTT $(0-210 \mathrm{mg} / \mathrm{L})$ inhibited the esterase activity of grape skin (Figure 1). When $\mathrm{K}_{2} \mathrm{~S}_{2} \mathrm{O}_{5}$ was used, esterase activity of the $\mathrm{B}$ extract decreased until the reducing agent concentration reached $150 \mathrm{mg} / \mathrm{L}$, and then the trend reached a plateau. By increasing the concentration of $\mathrm{K}_{2} \mathrm{~S}_{2} \mathrm{O}_{5}$ up to $150 \mathrm{mg} / \mathrm{L}$, esterase activity decreased to $20 \%$ of initial activity and stabilized. The inhibition of esterase activity for the no $\mathrm{B}$ extract was faster at the beginning of the curve and reached $20 \%$ of initial activity at a concentration of $75 \mathrm{mg} / \mathrm{L}$ of $\mathrm{K}_{2} \mathrm{~S}_{2} \mathrm{O}_{5}$. Esterase activity was completely inhibited with increasing doses of reducing agent. DTT inhibited the esterase activity of the two grape skin extracts, but to a lesser extent (Figure 1). As with the previous case, the decrease of enzymatic activity of the B extract was more gradual, and esterase activity only dropped to $60 \%$ of initial activity upon addition of the maximum amount of DTT $(210 \mathrm{mg} / \mathrm{L})$. The activity of the no B extract was inhibited to $40 \%$ of initial activity with addition of $30 \mathrm{mg} / \mathrm{L}$ of DTT; this activity level then remained constant. Previous studies ${ }^{32}$ have shown that, at a concentration of $4 \mathrm{mmol} / \mathrm{L}$, the reducing agent DTT had a low inhibitory effect (about $75 \%$ of residual activity); this agrees with our results showing residual activity at the same DTT concentration of about $90 \%$ and $65 \%$ for the B and no B samples, respectively. On the other hand, ${ }^{33}$ different studies have shown enhancement of esterase activity in the presence of DTT and $\beta$-mercaptoethanol when using p-nitrophenyl esters as the substrate. In the present study, the reducing agent, added both during grape skin extraction and study of enzyme activity, had an inhibitory effect on activity. This could be due to an irreversible interaction between the enzyme and the reducing agent during grape skin extraction, accompanied by residual enzymatic activity that remains stable even when other reducing agents are added. This observation could have implications in enology, where the addition of reducing compounds to wines is a very common practice. Addition of reducing compounds could have effects on esterase activity, with consequences for the organoleptic characteristics of the wine being produced.

To verify extraction with and without $\beta$-mercaptoethanol extract proteins (specifically, esterases) from the grape skin 

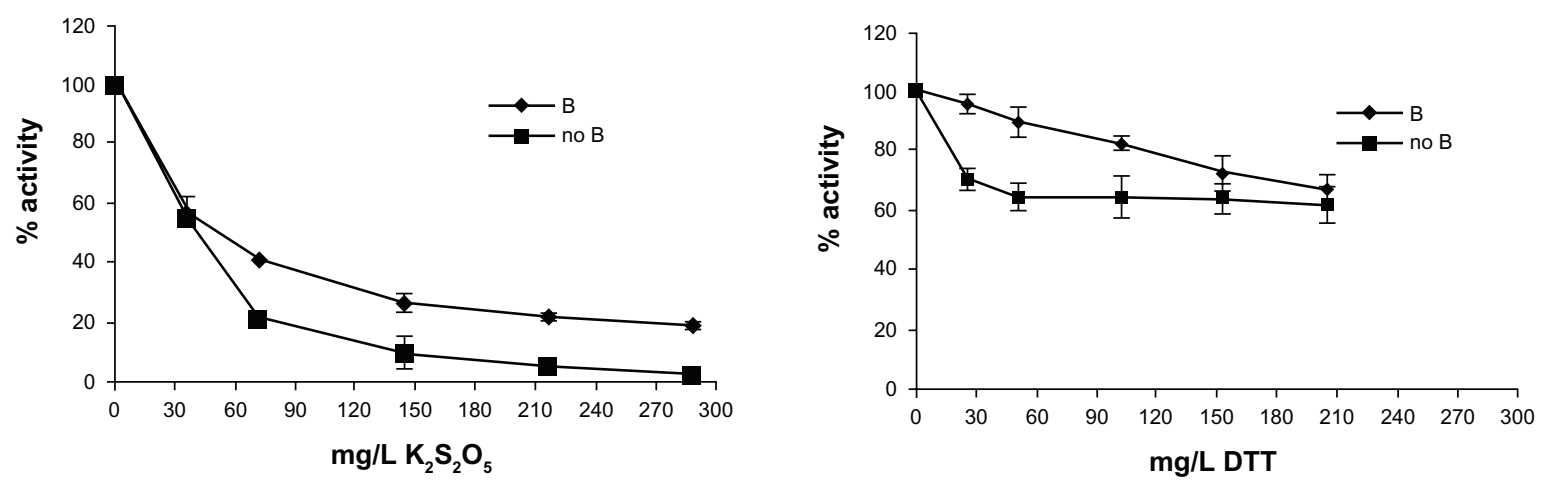

Figure I Esterase activity of grape skin of Bianchetta trevigiana extracted with (B) and without $\beta$-mercaptoethanol (no B), quantified with 2-naphthyl acetate and studied in the presence of increasing concentrations of $\mathrm{K}_{2} \mathrm{~S}_{2} \mathrm{O}_{5}$ and DTT.

in a qualitatively different way, native gel electrophoresis was carried out. Because the samples had very low solubility in aqueous buffer, it was necessary to add Deriphat detergent both to the electrophoretic buffer and to the grape skin extracts. ${ }^{26}$ The zymogram reveals a unique esterase band for the three substrates (Figure 2), with equal amounts of protein loaded. As visualized by the intensity of dye and by the fluorescence of the enzymatic bands, the esterase activity is stronger in the no B extracts, as previously verified with the spectrophotometric assay. Additionally, the enzymatic band resulting from the use of $2 \mathrm{NA}$ as a substrate is more intense than the band revealed with $2 \mathrm{NB}$ as substrate, in agreement with the results presented in Table 1 . The enzymatic method using FDA as a substrate is the most sensitive. ${ }^{25}$ The comparison between the two samples (B and no B) by electrophoretic analysis of protein extracts visualized by Coomassie confirms the same patterns of bands.

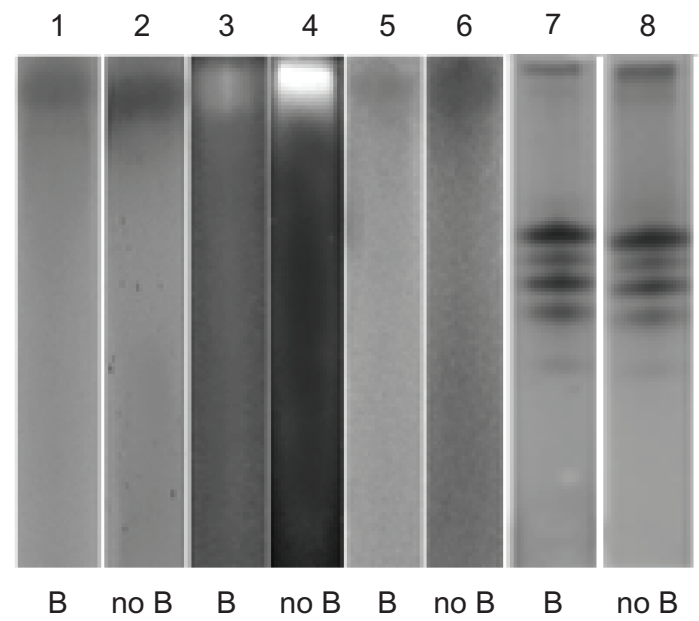

Figure 2 Deriphat polyacrylamide gel electrophoresis $(T=8.5 \%)$.

Notes: Esterase activity of grape skin of Bianchetta trevigiana extracted with (B) and without $\beta$-mercaptoethanol (no B) and visualized in the presence of 2-naphthyl acetate (lanes I and 2), fluorescein diacetate (lanes 3 and 4), and 2-naphthyl butyrate (lanes 5 and 6). Lanes 7 and 8 show the electrophoretic protein patterns of the two samples.
Samples were also electrophoresed under denaturing conditions using SDS. Figure 3 shows the zymograms of esterase activity visualized with 2NA (lanes 1 and 2) and FDA (lanes 3 and 4) as substrates. As shown in the zymogram obtained under native conditions (Figure 2), enzymatic bands of Figure 3 differ only in intensity of color and fluorescence. Whereas the zymogram in D-PAGE revealed only a single band (Figure 2), SDS-PAGE showed two enzymatic bands. This could be due to comigration of the enzymes under native conditions that migrate separately in SDS-PAGE or due to the loss of an isoform during the separation in D-PAGE. SDS-PAGE (Figure 3) shows the same protein pattern both for the B and no B extracts. The zymogram of Figure 3 was studied by densitometric analysis to visualize differences of intensity in the two esterase bands. As shown in Figure 4, the densitograms of esterase activity in the two samples are different. The peaks generated by the B extract samples have

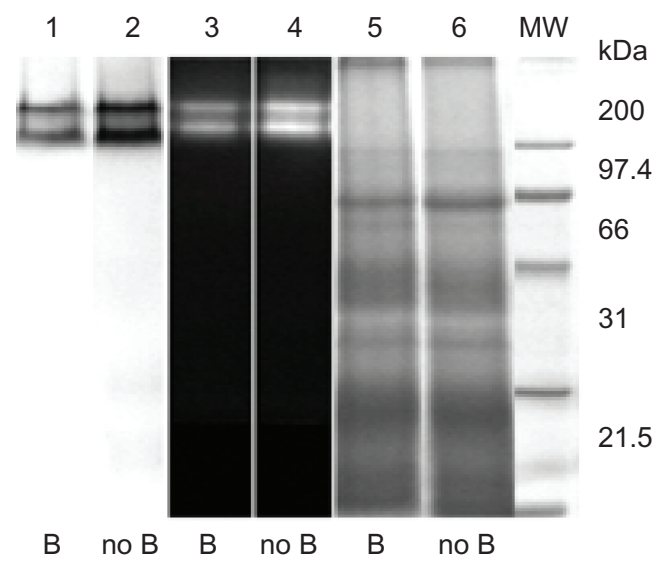

Figure 3 Sodium dodecyl sulfate polyacrylamide gel electrophoresis $(T=12 \%)$. Notes: Esterase activity of grape skin of Bianchetta trevigiana extracted with (B) and without $\beta$-mercaptoethanol (no $B$ ) and visualized in the presence of 2-naphthyl acetate (lanes $I$ and 2) and fluorescein diacetate (lanes 3 and 4). Lanes 5 and 6 visualized in the presence of Coomassie Brilliant Blue show the electrophoretic protein patterns of the two samples. The molecular weight is expressed in $\mathrm{kDa}$. Abbreviation: MW, molecular weight. 
A

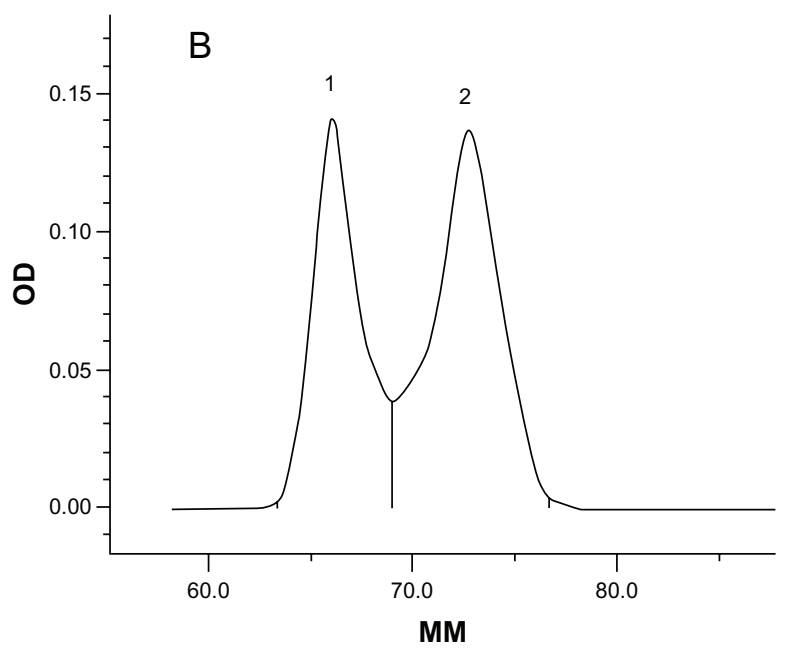

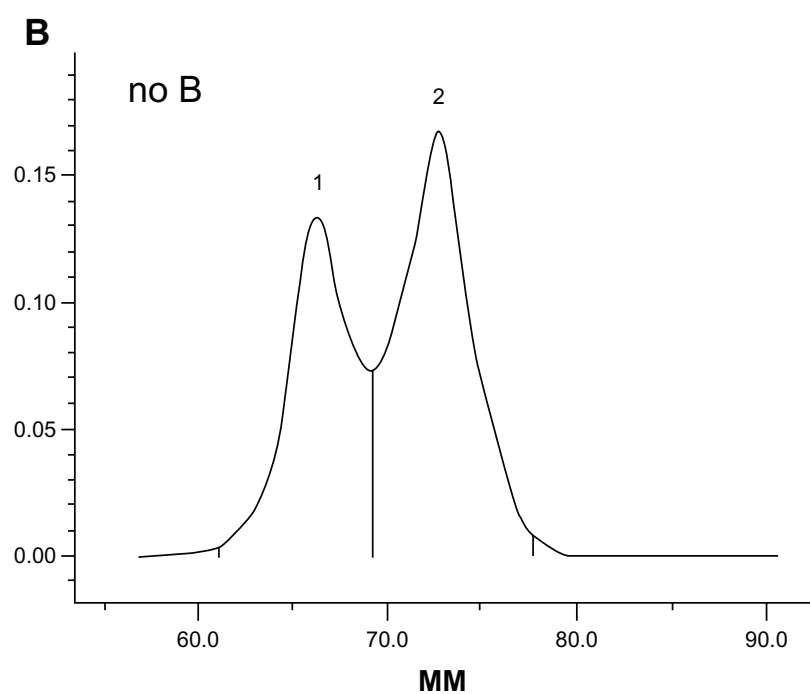

Figure 4 Densitometric analysis of the sodium dodecyl sulfate polyacrylamide gel electrophoresis shown in Figure 3.

the same height, while those of the no B samples have different heights. The reducing agent could affect the esterase activity of one of the two isoforms. The $\beta$-mercaptoethanol, by reducing amino acids such as cysteine that are present in the esterase isoforms, could perhaps partially affect the enzymatic activity. In addition, partial inhibition of only one isoform may be considered a result of the different amino acid composition of the two esterases.

\section{Conclusion}

Esterase, a ubiquitous class of enzymes in living organisms, is present in the cells of $B$. trevigiana grape skin. Different esterase isoforms can be visualized not only in native conditions but also in denaturing conditions. This latter condition allowed visualization of two isoforms with differing functional intensity in reducing (B) and nonreducing (no $\mathrm{B}$ ) treatment during enzyme extraction from grape skin. Increasing doses of reducing agents such as $\mathrm{K}_{2} \mathrm{~S}_{2} \mathrm{O}_{5}$, usually added during winemaking, affect esterases by lowering their activity. Because this enzyme is involved in the hydrolysis and synthesis of esters, addition of reducing agents could affect the aromatic profile of wine.

\section{Acknowledgments}

This research was supported by grants from Distretti del Vino. The authors thank the Consorzio per la tutela dei vini Montello e Colli Asolani, Montelvini SpA, and Federico Zocca, Stefano Nandi, and Diego Vanzella for technical assistance.

\section{Disclosure}

The authors report no conflicts of interest in this work.

\section{References}

1. Calò A, Paronetto L, Rorato G. Regional history of the vine and wine in Italy: Veneto. Centro di cultura e civiltà contadina biblioteca internazionale "La Vigna" Vicenza. Unione italiana vini, editor. Italy; 1996.

2. Sumby KM, Grbin PR, Jiranek V. Microbial modulation of aromatic esters in wine: current knowledge and future prospects. Food Chem. 2010;121:1-16.

3. Lambrechts MG, Pretorius IS. Yeast and its importance to wine aromaa review. S Afr J Enol Vitic. 2000;21:97-129.

4. Suomalainen $H$. Yeast esterase and aroma esters in alcoholic beverages. J Inst Brew. 1981;87:296-330.

5. Schermers FH, Duffus JH, MacLeod A. Studies on yeast esterase. J Inst Brew. 1976;82:170-174.

6. Fukuda K, Kuwahata O, Kiyokawa Y, et al. Molecular cloning and nucleotide sequence of the isoamyl acetate-hydrolyzing esterase gene (EST2) from Saccharomyces cerevisiae. J Ferment Bioeng. 1983;82: $8-15$.

7. Lilly M, Bauer FF, Lambrechts MG, Swiegers JH, Cozzolino D, Pretorius IS. The effect of increased yeast alcohol acetyltransferase and esterase activity on the flavour profiles of wine and distillates. Yeast. 2006;23:642-659.

8. Matthews A, Grbin PR, Jiranek V. Biochemical characterisation of the esterase activities of wine lactic acid bacteria. Appl Microbiol Biotechnol. 2007;77:329-337.

9. Inoue Y, Trevanichim S, Fukuda K, Izawa S, Wakai Y, Kimura A. Role of esterase and alcohol acetyltransferase on production of isoamyl acetate in Hansenula mrakii. J Agric Food Chem. 1997;45: 644-649.

10. Peddie HAB. Ester formation in brewery fermentations. J Inst Brew. 1990;96:327-331.

11. Avedovech RM, McDaniel MR, Watson BT, Sandine WE. An evaluation of combinations of wine yeast and Leuconostoc oenos strains in malolactic fermentation of Chardonnay wine. Am J Enol Vitic. 1992;43:253-260.

12. Bartowsky EJ, Henschke PA. Malolactic fermentation and flavour. Aust Grapegrow Winemak. 1995;378:83-94.

13. Delaquis P, Cliff M, King M, Girard B, Hall J, Reynolds A. Effect of two commercial malolactic cultures on the chemical and sensory properties of Chancellor wines vinified with different yeasts and fermentation temperatures. Am J Enol Vitic. 2000;51:42-48.

14. Maicas S, Gil J-V, Pardo I, Ferrer S. Improvement of volatile composition of wines by controlled addition of malolactic bacteria. Food Res Int. 1999;32:491-496. 
15. Fujii T, Nagasawa N, Iwamatsu A, Bogaki T, Tamai Y, Hamachi M. Molecular cloning, sequence analysis, and expression of the yeast alcohol acetyltransferase gene. Appl Environ Microbiol. 1994;60: 2786-2792.

16. Fukuda K, Kiyokawa Y, Yanagiuchi T, et al. Purification and characterization of isoamyl acetate-hydrolyzing esterase encoded by the IAH1 gene of Saccharomyces cerevisiae from recombinant Escherichia coli. Appl Microbiol Biotechnol. 2000;53:596-600.

17. Saerens SMG, Verstrepen KJ, Van Laere SDM, et al. The Saccharomyces cerevisiae EHT1 and EEB1 genes encode novel enzymes with medium-chain fatty acid ethyl ester synthesis and hydrolysis capacity. J Biol Chem. 2006;281:4446-4456.

18. Türkben C, Söylemezoglu G, Ergül A, Agaoglu Y. Isoenzymatic polymorphism differentiation of Turkish grapevine cultivars by polyacrylamide gel electrophoresis. Biotechnology and Biotechnological Equipment. 2002;16:148-151.

19. Zocca F, Lomolino G, Curioni A, Spettoli P, Lante A. Detection of pectin methylesterase activity in presence of methanol during grape pomace storage. Food Chem. 2007;102:59-65.

20. Barnavon L, Doco T, Terrier N, Ageorges A, Romieu C, Pellerin P. Involvement of pectin methyl-esterase during the ripening of grape berries: partial cDNA isolation, transcript expression and changes in the degree of methylesterification of cell wall pectins. Phytochemistry. 2001;58:693-701.

21. Bradford MM. A rapid sensitive method for the quantification of microgram quantities of protein utilizing the principle of protein dye binding. Anal Biochem. 1976;72:248-254.

22. Bardi L, Dell'Oro V, Delfini C, Marzona M. A rapid spectrophotometric method to determine esterase activity of yeast cells in acqueous medium. J Inst Brew. 1993;99:385-388.

23. Lomolino G, Rizzi C, Spettoli P, Curioni A, Lante A. Cell vitality and esterase activity of Saccharomyces cerevisiae is affected by increasing calcium concentration. Agro Food Industry Hi-Tech. 2003;14:32-35.
24. Laemmli UK. Cleavage of structural proteins during the assembly of the head of bacteriophage T4. Nature. 1970;227:680-685.

25. Lomolino G, Lante A, Crapisi A, Spettoli P, Curioni A. Detection of Saccharomyces cerevisiae carboxylesterase activity after native and sodium dodecyl sulfate electrophoresis by using fluorescein diacetate as substrate. Electrophoresis. 2001;22:1021-1023.

26. Zocca F, Lomolino G, Spettoli P, Lante A. Deriphat 2-DE to visualize polyphenoloxidase in Moscato and Prosecco grapes. Electrophoresis. 2007;28:3992-3997.

27. Ribereau-Gayon P, Glories Y, Maujean A, Dubourdieu D. Phenolic compounds. In: Ribereau-Gayon P, editor. Handbook of Enology. New York, NY: Wiley and Sons; 2000;2.

28. Minussi RC, Rossi M, Bologna L, et al. Phenolic compounds and total antioxidant potential of commercial wines. Food Chem. 2003;82: $409-416$.

29. Wang W. Lyophilization and development of solid protein pharmaceuticals. Int J Pharm. 2003;203:1-60.

30. Oliveira-Collet SA, Collet MA, Machado MFPS. Differential gene expression for isozymes in somatic mutants of Vitis vinifera L. (Vitaceae). Biochem Syst Ecol. 2005;33:691-703.

31. Kanwar SS, Kaushal RK, Jawed A, Gupta R, Chimni SS. Methods for inhibition of residual lipase activity in colorimetric assay: a comparative study. Indian J Biochem Biophys. 2005;42:233-237.

32. Smacchi E, Gobbetti M, Rossi J, Fox PF. Purification and characterization of an extracellular esterase from Arthrobacter nicotianae 9458. Lait. 2000;80:255-265. French.

33. Tekedar HC, Sanl1-Mohamed G. Molecular cloning over expression and characterization of thermoalkalophilic esterases isolated from Geobacillus sp. Extremophiles. 2011;15:203-211.
International Journal of Wine Research

\section{Publish your work in this journal}

The International Journal of Wine Research is an international, peer-reviewed open-access, online journal focusing on all scientific aspects of wine, including: vine growing; wine elaboration; human interaction with wine; and health aspects of wine The journal provides an open access platform for the reporting

\section{Dovepress}

of evidence based studies on these topics. The manuscript management system is completely online and includes a very quick and fair peer-review system, which is all easy to use. Visit http://www.dovepress.com/testimonials.php to read real quotes from some of our published authors. 